\title{
MENINGKATKAN HASIL BELAJAR SISWA DENGAN MENYELESAIKAN SOAL LATIHAN MATEMATIKA MELALUI PEMBATASAN WAKTU PADA SETIAP PERTEMUAN
}

\author{
Enung Puryati \\ SMP Negeri 1 Cianjur \\ nungpuryati@gmail.com
}

\begin{abstract}
ABSTRAK
Dalam pengajaran matematika banyak sekali kesulitan yang dihadapi siswa sehingga membuat siswa jenuh banyaknya soal-soal yang di bahas, bukan menambah keberhasilan siswa tetapi membuat siswa beranggapan negatif terhadap gurunya, oleh sebab itu kombinasi metode latihan dengan metode pengajaran lainnya sangat diperlukan. Untuk mengatasi hal-hal tersebut di atas, perlu diusahakan suatu teknik latihan yang efektif dan lebih berhasil dalam pencapaian tujuan belajar mengajar, salah satu alternatifnya adalah penerapan pembatasan waktu dalam menyelesaikan soal latihan matematika pada setiap pertemuan. Penelitian ini bertujuan untuk mengetahui sejauh mana meningkatkan hasil belajar siswa dalam menyelesaikan soal latihan matematika melalui pembatasan waktu pada setiap pertemuan. Subjek pada penelitian ini kelas IX J SMPN 1 Cianjur pada semester genap tahun pelajaran 2016/2017. Berdasarkan pengujian maka hasil penelitian ini dapat disimpulkan bahwa pembatasan waktu dalam meningkatkan hasil belajar dari sebelumnya di kelas IX SMPN1 Cianjur. Implikasinya dalam pengajaran matematika dapat meningkatkan hasil belajar siswa dalam matematika.
\end{abstract}

Kata Kunci : pembatasan waktu, matematika, latihan soal

\section{PENDAHULUAN}

Pendidikan atau yang di sampai kan dalam pengertian pengajaran adalah suatu usaha yang sistimatik dan terarah pada perubahan-perubahan tingkah laku menuju kedewasaan anak didik "(Winarno Surakhmad, 1980 : 4). Perubahan tingkah laku pada anak didik itu menuju pada suatu proses yang disebut dengan pendidikan. Tanpa proses itu maka perubahan tersebut tidak mungkin terjadi dan tujuan pendidikan tidak akan tercapai.

Di dalam proses pendidikan yang dalam hal ini proses belajar mengajar di sekolah sangat di perlukan hubungan aktif dua arah antara guru dengan siswa, tetapi hubungan aktif dua arah tersebut tidak hanya hubungan aktif dan tujuan melainkan hubungan aktif yang diikat oleh tujuan pendidikan.

Dalam usaha guru membantu siswa untuk mencapai tujuan itu sebaik-baiknya maka guru perlu memilih metode yang di anggap paling sesuai untuk keperluan pada saat itu dengan memperhitungkan suasana dan sarana yang ada, makin baik metode yang 
dipergunakan makin efektif pula pencapaian tujuan . Dengan mengetahui kelemahan dan kelebihan berbagai metode pengajaran maka guru akan lebih mudah memilih kombinasi berbagai metode yang sesuai untuk situasi dan kondisi yang dihadapi.

Di dalam pengajaran matematika banyak sekali soal yang harus di bahas. Oleh karena itu, kombinasi metode latihan dengan metode pengajaran lainnya yang sesuai dan sangat diperlukan. Untuk mencapai tingkat penguasaan secara optimal terhadap mata pelajaran matematika maka siswa harus melakukan latihan secara aktif, namun dalam kenyataannya peneliti sering melihat siswa kurang aktif dalam kegiatan latihan. Hal tersebut disebabkan oleh karena guru tidak dapat melakukan pengawasan kepada seluruh siswa, apabila situasi demikian tidak dibatasi maka proses belajar mengajar secara keseluruhan kurang berhasil.

Sementara itu pada saat latihan siswa dapat menyelesaikan soal sebanyak mungkin, karena dengan menyelesaikan sebanyak mungkin soal maka diharapkan siswa dapat menguasai materi yang sedang di ajarkan.namun berhubung waktu jam pelajaran yang terbatas maka hanya sedikit sekali soal yang dapat diselesaikan oleh siswa selama kegiatan latihan di kelas. Apabila hal tersebut terjadi terus menerus maka akan sulit dicapai tingkat penguasaan siswa terhadap mata pelajaran matematika secara optimal.

Selain itu, biasanya guru hanya dapat memberikan bimbingan kepada beberapa siswa saja sehingga minat atau tingkat kesulitan siswa yang lainnya kurang terawasi,peneliti mengetahui bahwa minat maupun tingkat kesulitan terhadap materi yang sedang di ajarkan adalah hal yang perlu di ketahui oleh setiap guru sebagai dasar untuk membuat kebijakan dalam rangka perbaikan atau pengembangan individu siswa sesuai dengan potensi yang dimiliki.

Perlu upaya dalam mengatasi hal tersebut dengan teknik latihan yang efektif agar lebih berhasil dalam pencapaian tujuan belajar mengajar. Salah satu alternatifnya adalah menerapkan pembatasan waktu dalam penyelesaian latihan soal matematika. Maier (1985:108), mengemukakan bahwa pembatasan waktu dalam menyelesaikan soal-soal tidak pasti berpengaruh negatif terhadap hasil belajar siswa.

Pada teknik latihan ini siswa harus selalu siap menyelesaikan soal dalam batas waktu yang ditentukan. Sehubungan dengan hal tersebut maka akan tertanam disiplin waktu bagi siswa dalam setiap menyelesaikan soal dalam hal ini Bono (1990:180) mengemukakan 
bahwa disiplin waktu membuat siswa berfikir lebih berhati-hati dan terpusat pada pekerjaan, sehingga lambat laun ia akan lebih pandai menyelesaikan soal dengan baik dan benar.

Berdasarkan latarbelakang masalah yang telah dikemukakan sebelumnya dalam penelitian ini dirumuskan dalam bentuk pertanyaan -pertanyaan. Apakah dengan pembatasan waktu dalam menyelesaikan soal-soal latihan mata pelajaran matematika dapat meningkatkan hasil belajar siswa?

\section{Hakekat Belajar dan Latihan}

Belajar adalah perubahan tingkah sebagai hasil adanya pengalaman ,perubahanperubahan dalam belajar yang bersifat kontinyu, fungsional,positif,aktif, dan permanen seta perubahan -perubahan tersebut berlangsung secara sadar dan bertujuan (Effendi dan Praja 1995:104).

Hasil belajar yang di capai merupakan hasil interakti antara berbagai factor yang mempengaruhi, baik dari dalam (1987diri ( faktor internal) maupun dari luar (faktor eksternal) individu yang tergolong faktor internal adalah faktor jasmani, psikologi ( Kecerdasan, minat, sikap, motivasi, dan lain-lain),dan faktor kematangan fisik, sedangkan yang tergolong faktor eksternal adalah lingkungan, social, budaya (adat istiadat,ilmu pengetahuan, teknologi), faktor lingkungan fisik ( fasilitas belajar, iklim,dan faktor lingkungan spiritual atau keagamaan (A.Tabrani Rusyan,Atang Kusdinar,dan Zainal Arifin, 1989:81).

Faktor yang terpenting dalam belajar adalah adanya latihan-latihan yang kontinu, Teori Conditioning dari Watson. Betapa pentingnya latihan dalam proses belajar. Dalam kegiatan latihan di kelas, siswa perlu mendapatkan bimbingan yang terarah dari guru, bimbingan ini bertujuan untuk membantu siswa dalam mencapai hasil optimal sesuai dengan kondisi dan potensi yang dimiliki siswa.

Di dalam latihan yang pertama-tama di perhatikan adalah ketepatan (kebenaran) kemudian barulah kecepatannya dan pada akhirnya kedua-duanya harus tercapai sebagai kesatuan "(Surakhmad 1980 : 110). Untuk memenuhi hal tersebut maka dalam latihan diberlakukan teknik yang memungkinkan seorang guru dapat memperhatikan ketepatan (kebenaran) dan kecepatan siswa dalam menyelesaikan soal latihan. 
Salah satu teknik yang dimaksud adalah teknik pembatasan waktu pada setiap pertemuan, yang diberlakukan kepada siswa dalam menyelesaikan soal latihan serta tidak diberikan nilai bagi siswa yang tidak menyelesaikan dengan tepat dalam waktu yang telah di tentu

\section{Pembatasan Waktu dalam Menyelesaikan Soal Latihan}

Waktu merupakan sesuatu yang sangat berharga bagi manusia dalam hidupnya. Betapa pentingnya waktu bagi manusia. Cerney (1987:121) mengemukakan :Waktu merupakan komoditi yang wajar dan bernilai di dalamnya setiap segi pemikiran dan tindakan harus disinkronkan agar memberikan hasil yang diinginkan.

Agar memperoleh hasil yang diinginkan maka seseorang harus menggunakan waktu dengan sebaik-baiknya. Dalam hal ini Yusuf Qordowi (1991) mengemukakan bahwa yang terpenting bukanlah seseorang dapat melakukan banyak hal apapun pada waktu yang ditentukan.

Demikian pula dalam kegiatan belajar, yang terpenting bukan lah siswa dapat menyelesaikan sebanyak mungkin soal latihan pada saat kapanpun akan tetapi adalah siswa dapat menyelesaikan sebanyak mungkin soal latihan pada waktu yang ditentukan,atau dengan kata lain yang terpenting adalah efisiensi kerja siswa dalam menyelesaikan soal latihan. Oleh karena itu, maka seseorang guru harus menerapkan teknik latihan yang memungkinkan siswa dapat menyelesaikan sebanyak mungkin soal pada saat latihan di kelas.salah satu alternatifnya adalah penerapan pembatasan waktu yang diberlakukan terhadap siswa dalam menyelesaikan soal latihan dan tidak diberikan nilai bagi siswa yang tidak dapat menyelesaikan dengan tepat waktu yang ditentukan tersebut.

Di dalam teknik latihan ini, banyak soal yang diberikan kepada siswa berdasarkan perkiraan guru terhadap waktu yang diperlukan dalam setiap penyelesaian soal. Jika soal itu memerlukan waktu yang relative singkat (seperti soal yang kecepatan berhitung saja dalam pelajaran matematika), maka dalam waktu yang ditentukan itu dapat diberikan beberapa soal, akan tetapi jika soal itu memerlukan waktu yang relatif lama ( seperti soal yang menurut pemikiran yang mendalam), maka yang ditentukan itu hanya diberikan satu soal saja. Bagian terpenting disini adalah penyesuaian waktu dan banyaknya soal yang diberikan kepada siswa diusahakan agar setiap siswa tidak mempunyai kesempatan untuk melihat hasil pekerjaan temannya. Kemudian dalam waktu yang telah ditentukan siswa juga harus segera 
menyerahkan hasil pekerjaannya ke meja guru untuk diperiksa dan setelah hasil pekerjaannya itu dikembalikan lagi kepada siswa maka guru menyuruh siswa untuk menyelesaikan soal selanjutnya yang telah dipersiapkan oleh guru. Adapun bagi siswa yang tidak menyelesaikan soal dengan benar dalam waktu yang telah ditentukan atau terlambat maka tidak akan diberi nilai.

Tentang teknik latihan yang memperhatikan kecepatan dalam penyelesaian soal latihan ini,Winarno Surakhmat mengemukakan prinsip-prinsip latihan seperti yang telah dikemukakan terdahulu yaitu di dalam latihan yang pertama-tama perlu diperhatikan adalah ketepatan (kebenaran) kemudian barulah kecepatan dan pada ahirnya kedua-duanya harus tercapai sebagai suatu kesatuan bagi siswa dalam menyelesaikan soal.

Herman Maier (1985:108), mengemukakan bahwa sanya pembatasan waktu dalam menyelesaikan soal-soal tidak pasti berpengaruh negatif terhadap prestasi belajar siswa. Di dalam teknik latihan ini siswa harus selalu siap menyelesaikan soal-soal dalam batas waktu yang ditentukan. Sehubungan dengan hal itu, maka akan tertanam disiplin waktu dalam setiap menyelesaikan soal, demikian menurut Edward de Bono (1990:180) yang mengemukakan, disiplin waktu membuat berfikir lebih berhati-hati dan terpusat pada pekerjaannya,sehingga lambat laun ia menjadi lebih pandai memikirkan dengan jelas.

Belajar akan lebih berhasil dan mendapatkan kepuasan dalam belajar apabila siswa mengetahui kemajuan-kemajuan yang telah dicapainya atau kegagalan-kegagalan yang telah dilakukannya. Dengan demikian dapat dikatakan bahwa dengan latihan siswa akan mendapat kepuasan dan lebih berhasil dalam belajarnya.

Bersamaan dengan itu minat maupun tingkat kesulitan siswa terhadap materi yang diberikan akan dapat segera diketahui oleh guru, yang selanjutnya akan diberikan bimbingan bagi siswa yang mengalami kesulitan agar dapat mengikuti latihan dengan aktif. Dengan demikian maka seluruh siswa akan aktif dalam kegiatan latihan. Sehingga tujuan belajar mengajar akan tercapai lebih optimal.

Pada saat mengikuti tes hasil belajar, siswa harus sudah mempunyai gambaran/rencana untuk menyelesaikan soal-soal tes, hal ini disebabkan banyaknya soal yang telah dibahas selama kegiatan latihan di bawah bimbingan guru. Selainitu siswa dapat menguasai waktu yang diberikan ,hal ini karena terbiasanya siswa menyelesaikan soal-soal dengan batasan waktu tertentu. Carney (1989) mengemukakan bahwa jika kita menguasai 
waktu disertai dengan perencanaan yang baik maka kita perlu tergesa-gesa mengerjakan sesuatu pada menit-menit terakhir yang dapat mengakibatkan kegagalan fatal.

Robert W Olson (1989:222) mengemukakan perencanaan dan adanya batas waktu bagi tercapainya hasil yang diharapkan dapat menempatkan diri kita pada jalur yang seharusnya dan akan memusatkan energi yang dibutuhkan untuk menjadikan tugas-tugas yang dihadapi dapat terlaksana tepat pada waktunya. Sehingga kesimpulannya dapat dikatakan bahwa dengan rencana dan penguasaan waktu siswa dapat menyelesaikan soal tes dan dapat memperoleh prestasi yang di harapkan.

\section{Hakekat Matematika}

Istilah matematika berasal dari kata yunani yaitu mathein atau menthein yang artinya mempelajari (Andi Hakim Nasution, 1982:12). Sampai saat ini belum ada kesepakatan diantara matematikawan mengenai definisi matematika. menurut Sujono (1988:4) matematika adalah ilmu pengetahuan tentang penalaran yang logis.

Di dalam matematika pokok-pokok bahasan tersusun mulai dari yang mendasar hingga kepada pengembangannya. Oleh sebab itu setiap orang yang ingin mempelajari matematika dengan baik maka harus melalui jalur-jalur yang pasti dan tersusun secara logis.

Pada saat ini kemampuan melakukan proses dasar matematika merupakan suatu kebutuhan yang penting bagi setiap orang.Untuk membilang,menambah,mengukur,menjual,membeli,yang kesemuanya itu adalah proses dasar matematika sederhana yang menunjukakan bagaimana pentingnya matematika di dalam kehidupan sehari-hari.

Dalam mempelajari ilmu pengetahuan lainnya seperti Fisika, Teknik, Pertanian, dan lain-lain akan lebih mudah apabila dapat menguasai matematika sehingga dapat dikatakan bahwa penguasaan matematika menjadi modal dasar dalam mempelajari ilmu pengetahuan lainnya terutama yang berkaitan dengan hitung menghitung.

Dalam kehidupan sehari-hari kemampuan mengeluarkan pendapat dengan singkat, jelas, tepat, dan langsung menuju sasaran adalah modal yang berharga. Setiap orang yang belajar matematika dituntun untuk menyatakan pendapat dengan singkat dan tepat adalah merupakan keindahan tersendiri.

Dalam dunia modern sekarang ini tidak ada orang yang tidak memerlukan matematika baik untuk keperluansehari-hari maupun untuk perkembangan ilmu dan teknologi 


\section{Hakekat Hasil Belajar}

Dalam proses belajar mengajar sangat diperlukan hubungan interaktif guru dan siswa hubungan tersebut bukan merupakan hubungan aktif tanpa tujuan, melainkan yang diikat oleh tujuan pengajaran yang pada dasarnya merupakan rumusan tingkah laku dan kemampuan yang harus di capai dan dimiliki siswa setelah menerima pengalaman belajarnya. Isi tujuan pengajaran pada hakekatnya adalah hasil yang diterapkan.

Hasil belajar dapat dibedakan dalam beberapa kategori menurut Benyamin S Bloom secara garis besar di bagi menjadi tiga kategori yaitu :

a. Ranah kognitif : Berkenaan hasil belajar intelektual

b. Ranah Afektif : Berkenaan dengan sikap

c. Ranah Psikomotor : Berkenaan dengan hasil belajar keterampilan dan kemampuan bertindak “(Nana Sudjana $1990: 22-23$ ).

Diantara ke tiga ranah tersebut,ranah kognitif adalah yang paling banyak dinilai oleh para guru, karena berkaitan dengan kemampuan para siswa dalam menguasai materi pelajaran.

Dalam proses belajar-mengajar guru harus mengetahui hasil belajar yang telah dicapai oleh siswa, sehingga dengan demikian dapat diambil tindakan perbaikan pengajaran dan juga perbaikan terhadap siswa yang mengalami kesulitan, misalnya dengan melakukan strategi pengajaran serta memberikan bantuan belajar dan bimbingan kepada siswa.

Untuk mengetahui hasil belajar siswa,biasanya guru hasil tes belajar kepada siswa,dan dari hasil tersebut guru akan melakukan tindakan-tindakan yang dianggap perlu guna pencapaian hasil pembelajaran yang optimal.

\section{METODOLOGI PENELITIAN}

Metode penelitian ini berjenis penelitian tindakan kelas (PTK). Subjek pada penelitian ini kelas IX J SMPN 1 Cianjur pada semester genap tahun pelajaran 2016/2017. pokok bahasan yang diberikan, yaitu volume dan luas sisi bangun ruang yang dinyatakan dengan $85 \%$ dari jumlah siswa menadapatkan nilai di atas 6,5. Di dalam penelitian ini digunakan tes sub sumatif tertulis dalam bentuk objektif tes,yaitu untuk mengetahui hasil belajar belajar siswa. Tes ini terdiri atas 30 soal dengan empat pilihan. 
Adapun hipotesis tindakannya yaitu pembatasan waktu dalam menyelesaikan soal latihan matematika dapat meningkatkan hasil belajar matematika siswa

\section{HASIL DAN PEMBAHASAN}

Tabel 1. Hasil Belajar Siswa dalam 6 Pertemuan

\begin{tabular}{|c|c|c|c|c|c|}
\hline \multirow[t]{4}{*}{ NO } & \multirow[t]{4}{*}{ PERTEMUAN KE } & \multirow{4}{*}{$\begin{array}{c}\text { BANYAKNYA } \\
\text { SISWA YANG } \\
\text { MENJAWAB } \\
\text { BENAR }\end{array}$} & \multirow{4}{*}{$\begin{array}{c}\text { KETERCAPAIAN } \\
\%\end{array}$} & \multicolumn{2}{|c|}{ KETUNTASAN } \\
\hline & & & & \multirow[t]{3}{*}{ YA } & \multirow[t]{3}{*}{ TIDAK } \\
\hline & & & & & \\
\hline & & & & & \\
\hline 1. & 1 & 30 Orang & 88,6 & $\mathrm{~V}$ & \\
\hline 2. & 2 & 31 Orang & 90,9 & $\mathrm{~V}$ & \\
\hline 3. & 3 & 30 Orang & 88,6 & $\mathrm{~V}$ & \\
\hline 4. & 4 & 27 Orang & 84,8 & & V \\
\hline 5. & 5 & 21 Orang & 68,2 & & V \\
\hline 6. & 6 & 31 Orang & 90,9 & $\mathrm{~V}$ & \\
\hline \multicolumn{3}{|c|}{ Rata-rata $(\%)$} & 85,3 & & \\
\hline \multicolumn{3}{|c|}{ Tuntas $(\%)$} & & 66,7 & \\
\hline \multicolumn{3}{|c|}{ Tidak Tuntas (\%) } & & & 33.3 \\
\hline
\end{tabular}

Setiap pertemuan kegiatan belajar mengajar pada langkah penerapan siswa diberikan 4 atau 5 soal dengan pembatasan waktu dalam bentuk esai, rata-rata waktu yang diberikan untuk menyelesaikan soal itu 3 sampai 4 menit setiap soalnya disesuaikan dengan tingkat kesulitan atau bobot soal, banyaknya siswa yang mengikuti tes 35 orang.

Pada Tabel 1, dapat diperoleh bahwa banyak siswa yang dapat menyelesaikan soal dengan tepat dan benar pada setip pertemuan kegiatan belajar mengajar sesuai dengan dengan evaluasi ke 1 yaitu siswa yang tuntas 66,7 \% dan yang tidak tuntas 33,3\% dan ratarata keberhasilan siswa $85,3 \%$ dalam 6 pertemuan.

Penyelesaian soal-soal dengan pembatasan waktu membuat anak bersemangat untuk mengumpulkan jawabannya ke meja guru dan akan membuat siswa percaya diri. Jika melihat hasil belajar setiap pertemuan cukup baik.

Tabel 2. Hasil Belajar Siswa per Individu

\begin{tabular}{lcccccc}
\hline NO & $\begin{array}{c}\text { NO } \\
\text { ABSEN } \\
\text { SISWA }\end{array}$ & $\begin{array}{c}\text { BANYAK SOAL } \\
\text { YANG DI JAWAB } \\
\text { BENAR }\end{array}$ & NILAI & KETERCAPAIAN & KETUNTASAN \\
\hline $\mathbf{1 .}$ & 001 & 25 & 83,3 & 83,3 & $\mathrm{~V}$ & \\
\hline $\mathbf{2 .}$ & 002 & 18 & 60,0 & 60 & $\mathrm{~V}$ \\
\hline $\mathbf{3 .}$ & 003 & 25 & 83,3 & 83,3 & $\mathrm{~V}$ & \\
\hline $\mathbf{4 .}$ & 004 & 30 & 100 & 100 & $\mathrm{~V}$ \\
\hline $\mathbf{5 .}$ & 005 & 27 & 90 & 90,0 & $\mathrm{~V}$ \\
\hline
\end{tabular}


Jurnal PRISMA Universitas Suryakancana

\begin{tabular}{|c|c|c|c|c|c|c|}
\hline 6. & 006 & 27 & 90 & 90,0 & V & \\
\hline 7. & 007 & 26 & 86,7 & 86,7 & V & \\
\hline 8. & 008 & 17 & 56,7 & 56,7 & & V \\
\hline 9. & 009 & 25 & 83.3 & 83,3 & V & \\
\hline 10. & 010 & 28 & 93,3 & 93,3 & V & \\
\hline 11. & 011 & 26 & 86,7 & 86,7 & V & \\
\hline 12. & 012 & 26 & 86,7 & 86,7 & V & \\
\hline 13. & 013 & 25 & 83,3 & 83,3 & V & \\
\hline 14. & 014 & 23 & 76,7 & 76,7 & V & \\
\hline 15. & 015 & 25 & 83,3 & 83,3 & V & \\
\hline 16. & 016 & 23 & 76,7 & 76.7 & V & \\
\hline 17. & 017 & 15 & 50 & 50 & & $\mathrm{~V}$ \\
\hline 18. & 018 & 28 & 93,3 & 93,3 & V & \\
\hline 19. & 019 & 15 & 50 & 50 & & V \\
\hline 20. & 020 & 30 & 100 & 100 & V & \\
\hline 21. & 021 & 25 & 83,3 & 83,3 & V & \\
\hline 22. & 022 & 23 & 76,7 & 76,7 & V & \\
\hline 23. & 023 & 23 & 76,7 & 76,7 & V & \\
\hline 24. & 024 & 25 & 83,3 & 83,3 & V & \\
\hline 25. & 025 & 20 & 66,7 & 66,7 & & $\mathrm{~V}$ \\
\hline 26. & 026 & 23 & 76,7 & 76,7 & $\mathrm{~V}$ & \\
\hline 27. & 027 & 25 & 83,3 & 83,3 & V & \\
\hline 28. & 028 & 29 & 96,7 & 96,7 & V & \\
\hline 29. & 029 & 23 & 76,7 & 76,7 & V & \\
\hline 30. & 030 & 23 & 76,7 & 76,7 & V & \\
\hline 31. & 031 & 24 & 80 & 80 & V & \\
\hline 32. & 032 & 23 & 76,7 & 76,7 & V & \\
\hline 33. & 033 & 23 & 76,7 & 76,7 & V & \\
\hline 34. & 034 & 25 & 83,3 & 83,3 & V & \\
\hline 35. & 035 & 23 & 76,7 & 76,7 & $\mathrm{~V}$ & \\
\hline \multicolumn{3}{|c|}{ RATA-RATA } & 80,3 & & & \\
\hline \multicolumn{3}{|c|}{ TUNTAS (\%) } & & \multicolumn{3}{|c|}{85,7} \\
\hline \multicolumn{3}{|c|}{ TIDAK Tuntas (\%) } & & & & 14,3 \\
\hline
\end{tabular}

Berdasarkan hasil pengolahan data pada Tabel 2, taraf ketuntasan belajar siswa sebesar $85,7 \%>85 \%$ maka hipotesis penelitian bagus dapat di terima. Setelah memberikan gambaran terhadap keberhasilan siswa dalam melaksanakan tes setiap pertemuan maka penulis memberikan upaya dengan pembatasan waktu dalam menyelesaikan soal yang lebih banyak berbentuk pilihan ganda dari 30 soal dengan empat pilihan.

\section{KESIMPULAN}

Berdasarkan penelitian ini dapat disimpulkan pembatasan waktu dalam menyelesaikan soal-soal latihan matematika sangat membantu terhadap peningkatan hasil belajar siswa dalam mata-pelajaran Matematika di kelas IX J,SMPN 1 Cianjur, dengan kriteria ketuntasan $86,36 \%$. 


\section{REFERENSI}

Arifin, Z., Kusdinar, \& Rusyan, A. Tabrani(1989). Pendekatan dalam Proses Belajar Mengajar. Bandung: Remaja Karya.

Carney, J. V. (1987). Berfikir Secara Dinamis. Bandung: Pionir Jaya.

Debono, E. (1990). Pelajaran Berfikir,(terjemahan Martin Samosir). Jakarta: Erlangga.

Effendi,U. E. \& Praja, J. S.(1995). Pengantar Psikologi. Bandung: Angkasa.

Maier, H. (1982). Konpedium Didaktik Matematika. Bandung: Remaja Karya.

Nasution, A. H. (1982). Landasan Matematika. Jakarta: Bhatara Karya Aksara.

Olson,W.(1989). Seni Berfikir Kreatif. Jakarta: Erlangga.

Purwanto, N. (1987). Pengantar Psikologi. Bandung: Remaja Karya.

Surakhman,W. (1980). Pengantar Interaksi Belajar Mengajar. Bandung : Tarsito.

Qordowi,Y. (1991).Waktu dalam Kehidupan Muslim. Jakarta: Firdaus. 